\title{
Knowledge Management - situation in Poland and Slovakia
}

\author{
Renáta Machová1,*, Zoltán Šeben ${ }^{1}$, Tibor Zsigmond ${ }^{1}$ and Annamária Bakulár ${ }^{1}$ \\ ${ }^{1}$ Univerzita J. Selyeho, Fakulta ekonómie a informatiky, Katedra manažmentu, Bratislavská cesta \\ 3322, Komárno, 94501, Slovenská Republika
}

\begin{abstract}
The aim of the study is to present the situation of knowledge management at Polish and Slovak companies. The first part contains the introduction. We describe the importance of human knowledge which is one of the main resources in companies' life. In the theoretical part define the meaning of the knowledge and describe knowledge management. In the next part we describe the objectives of this study and the methods used in our research. Our study is based on secondary data. In the practical part we present the state of Polish and Slovak companies in terms of KM. The last part contains the conclusions. Some similarities can be found between the two countries. Large companies are more engaged in knowledge at some level. The biggest obstacles to $\mathrm{KM}$ is that the management and the employees have less time and information about the KM processes. In order to improve in the future, it is worth raising the awareness of companies about the usefulness of KM.
\end{abstract}

\section{Introduction}

In recent decades companies have realized that one of the most important sources of competitive advantage are human resources. Within this knowledge plays a key role, much of which lies in the people themselves. Not only is it important to acquire the knowledge for organizations, it must be ensured that it is accessible to everyone in the organization who needs it. Furthermore, it is important that the already acquired knowledge should be reused in the future. On the other hand, enterprises have to act socially responsible while acquiring the knowledge. There are methods like copying or stealing the knowledge, which are't the most ethical ways for knowledge acquisition. Enterprises have to minimize the use of these methods to be socially accepted. These processes (knowledge acquisition, sharing, storing, etc.) require a certain degree of competence and care, which is why the term Knowledge Management has been created. The KM summarizes the activities defined above. Companies that do not manage knowledge properly may have great difficulties. Knowledge "doesn't manage itself." So, due to untold knowledge, it may be hidden inside the company to those who need it, but aren't aware of its presence. In this case, the necessary knowledge must be re-acquired in some way. This will definitely cost the organization. These costs include monetary, time and energy costs. Of course, there are also

\footnotetext{
*Corresponding author: machovar@ujs.sk
} 
costs associated with managing knowledge, but these are considered as a return on investment over time, to the benefit of companies. The aim of our paper was to learn about the spread of knowledge management among Polish and Slovakian companies.

In the first part of our study we review domestic and international literature and journals in more detail. The knowledge itself is presented, defined by the opinions of various internationally recognized professionals. In addition, researchers' definitions from the studied countries are included too. In the theoretical review, we also introduce the process of knowledge management.

\section{Theoretical background}

\subsection{What does knowledge mean?}

There is no unified definition that describes what knowledge means. The term has already been interpreted by several researchers based on different approaches. The work of Penrose [1] should be highlighted. According to her, some of the resources are physical while the other depends on people. The author also emphasized the growing importance of knowledge, but also added that it is a "vague" concept that cannot be treated as a solid factor.

At the end of the 20th century, further theories and studies were developed on the subject. It is important to mention the work of Davenport and Prusak [2]. In their book, "Working Knowledge: How to Organize What They Know", knowledge is a coherent unit of experience, values, contextual information, and expert knowledge that helps evaluate and incorporate new experiences and information. [3-5]

According to Chaudhry, Li and Ren [6] in the business and organizational sense, knowledge is the so-called "Know-how". So it is a mixture of insight, perception, experience and foresight. In other words, it is a unique blend of intellect and intuition that enables people to be aware of what and how to act.

It is also important to highlight the definition of Peter Drucker [7]. In his view, the basic significant economic resource nowadays is not capital, natural resources and labour but knowledge. Its definition reads as follows: "Traditional factors of production - land (natural factors), labour and capital - have not disappeared but have become secondary. They are easy to obtain when we have the right knowledge. Knowledge in the new sense means knowledge as a utility and as a means of achieving social and economic results." [7,8]

According to the interpretation of the Polish Wielka Encyklopedia [9], knowledge is the result of a cognitive act, but at the same time a reciprocal relationship between knowledge and cognition can be discovered. Knowledge is a consequence of cognition, and on the other hand, cognition largely presupposes knowledge.

Hittmár [10], a prominent figure in Slovak literature, also defines the meaning of knowledge in his book. According to his interpretation, knowledge is completely unstructured and is used inside the human mind. In its opinion, knowledge cannot be processed by information and communication technologies, so it depends on the conscious activity of its owner. This means that the owner cannot be anything other than human. Unlike data and information, it not only describes reality but also causes explanations and answers. This helps human to respond to the problems.

\subsection{Managing the knowledge - KM}

Companies need to manage their internal knowledge properly in order to be successful. Economically successful companies are aware of their goals. To achieve these goals, they 
need some tools. Knowledge is one of the main tools for achieving goals. It is another question how conscious this company is in managing this knowledge. In our opinion there are companies, especially smaller ones that do not consciously manage knowledge, but their goals "float in front of their eyes" and therefore do their best to achieve them - among other things they do everything to acquire and preserve the important knowledge. [3, 11, 12]

There are many definitions of knowledge management, but in essence, each term is similarly characterized. Bencsik [3] describes KM referring to Davenport and Prusak [2] and Gholami et al [13] as the management of all activities which aims mapping, gathering, systematizing, sharing, developing, leveraging internally accumulated and documented implicit knowledge, expertise and experience inside the organisation, etc. [4, 14]

\section{Aims and methodology}

We conducted a secondary research in our study. The results of the research show the situation of knowledge management in Polish and Slovakian enterprises. We studied the research of KPMG's local unit [15], Siuta-Tokarska [16] and Chmielewska-Muciek, Zinczuk [17]. In the case of Slovakia, our opportunities were relatively limited, as we found less previous researches on the subject. Finally, Gabris et al. [18] and Sujanova et al. [19] were the researches that we searched through. The authors examined the knowledge management of Slovak industrial companies. The disadvantage of these researches is the low number of items (based on 82 filled questionnaires). Another Slovak research is related to Tóbiás Kosár, Gódány and Szabó [20]. This study had a larger element count (360 respondents), but the research also examined other factors related to knowledge that aren't part of this study, so we could only use very little data from it.

\section{The situation of the KM}

\subsection{Polish enterprises}

\subsubsection{The state of knowledge management at polish corporations}

Firstly, we would like to present the results of a survey conducted by KPMG Polska - a local office of one of the world's leading audit, tax and business consulting firms. The research was conducted in 2004. 121 companies were surveyed, all of which were large companies, employing more than 250 people and with annual revenues in excess of $€ 40$ million. [15],

Only 15 percent of the companies participating in the research indicated that they had already implemented some kind of knowledge management programme, while another 31 percent stated that the implementation of knowledge management programme was being developed. More than 50 percent of the filling companies $(26+28$ percent $)$ indicated that they have not yet implemented any knowledge management program in the company and even 26 percent of them did not consider introducing a similar system at all. $[15,16]$ 

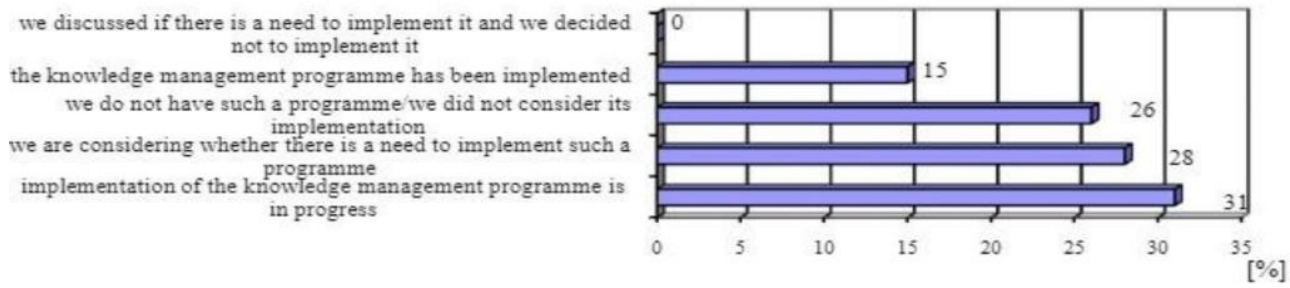

Fig. 1. The state of knowledge management at polish corporations. $[15,16]$

On a positive note, 28 percent of companies planned to introduce some kind of knowledge management program. Furthermore, the percentage of companies that had already discussed the introduction of knowledge management but still decided not to implement it did not reach a single percentage. $[15,16]$

Examining these data we have two observations - one positive and one negative. On the positive side, companies that have already discussed the issue of knowledge management have made a positive decision after the discussion. This can be assumed based on the first theorem ("we discussed if there is a need to implement it and we decided not to implement it"). Based on this, 28 percent of companies that indicated they are currently in the discussion phase are likely to introduce some kind of knowledge management program in their organization in the future. On the negative side - as explained above - the 26 percent of companies did not consider the implementation of such a programme. Overall, we assume that a quarter of corporations did not have adequate knowledge in terms of knowledge management. However, companies that were aware of the importance of knowledge management have already introduced it (15 percent), are in the process of implementing it (31 percent) or are considering implementing it (28 percent). $[15,16]$

In its research, KPMG [15] also addressed the specific problems of large companies that oppose the introduction of knowledge management. The figure below clearly shows the main causes.

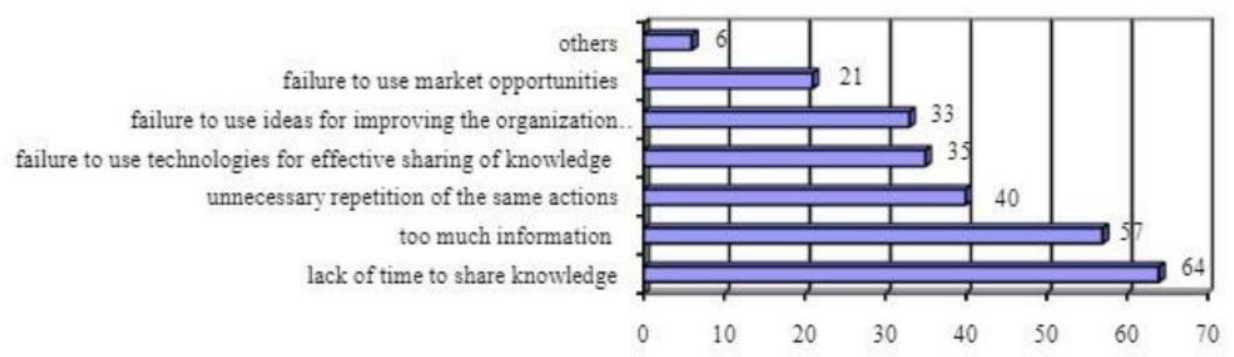

Fig. 2. Main factors motivating entrepreneurs to manage knowledge in the company. $[15,16]$ 
Based on this, it can be seen that in the case of corporations, the lack of time is what prevents the sharing and the transfer of knowledge, and thus also the proper development of knowledge management.

The research also revealed that in 18 percent of the companies surveyed, inadequate treatment of knowledge caused 5 percent loss in income. For another 7 percent, income fell by $5-10$ percent. For the remaining 65 percent losses are difficult to estimate. The loss can be assumed to be greatest for companies that do not employ any form of knowledge management at all. $[15,16]$

The results show that for the majority of corporations operating in Poland, only the board of directors ( 42 per cent) and senior management ( 21 per cent) are involved in the knowledge management process. 7 percent of middle management is involved, while only 1 percent of additional workers are involved in similar processes. $[15,16]$

\subsubsection{The state of knowledge management at polish SMEs}

According to the classification used in the European Union, all companies with less than 250 employees belong to one of the micro, small or medium-sized enterprises. These three types of companies are categorized into one group for most research. More than 99 percent of companies in Poland are SMEs. [16, 21]

According to a study [22] 25 percent of information sources for SMEs come from internal sources. Information is then obtained from clients (21 per cent), various exhibitions (12 per cent) and competitors (10 per cent).

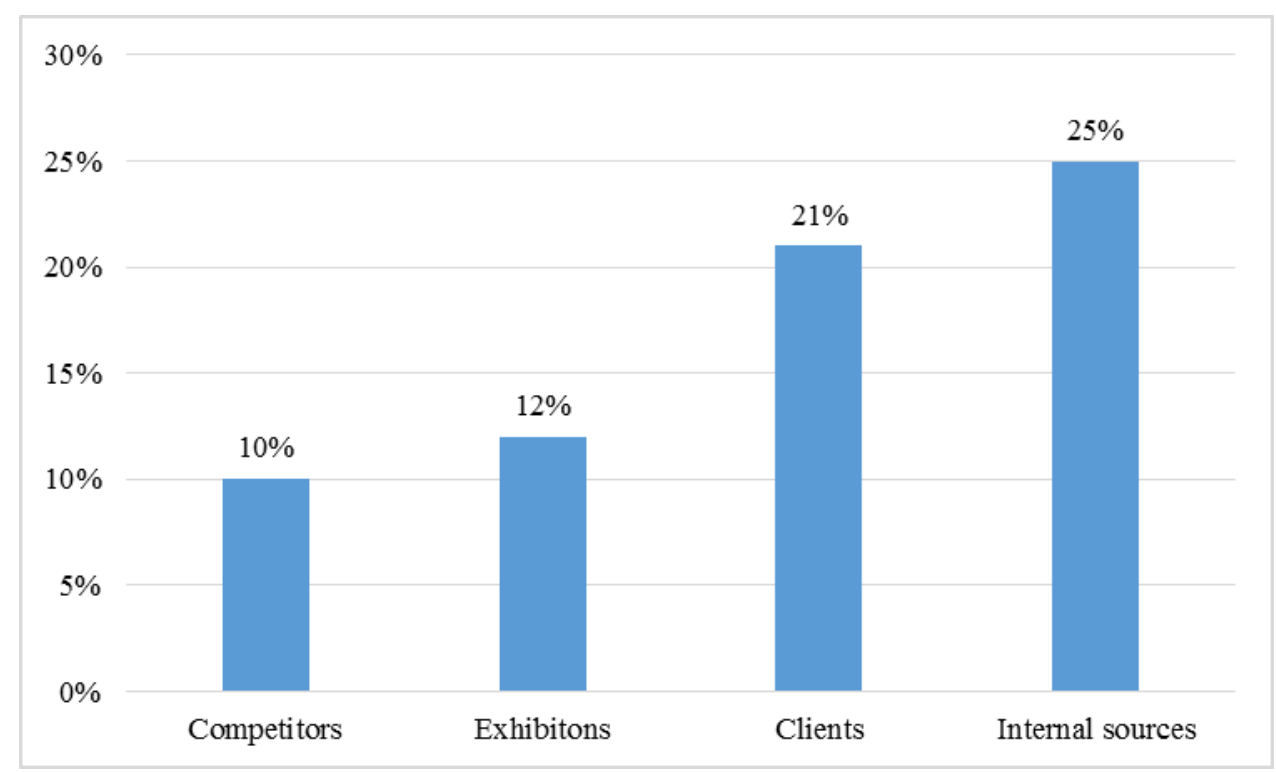

Fig. 3. Source of information for SMEs. Source: [22]

Wolański [23] points out that a group of SMEs in Poland is characterized by outstanding innovation, but most of them are medium-sized companies. Micro and small businesses tend to be less innovative.

Chmielewska-Muciek and Zinczuk [17] conducted studies among employees of 101 companies. The fillers of the questionnaire were from 1 large- 10 medium- and 90 small enterprises. 


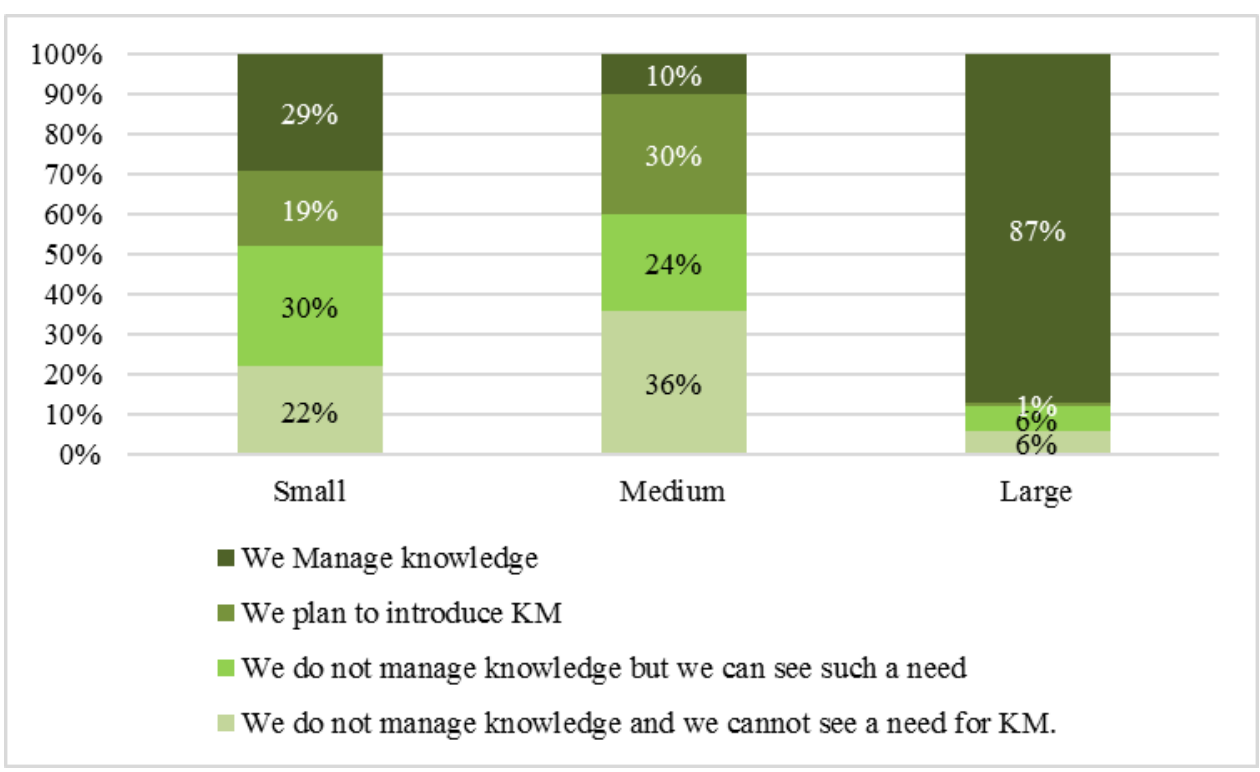

Fig. 4. Distribution of respondents' answers concerning the level of knowledge management. [17]

Based on the figure, it can be clearly seen that in large companies, employees found knowledge management to be very important. In the case of medium and small companies, the proportion of respondents who thought that knowledge management was important proved to be much lower. For these groups of companies, there was a much greater lack of interest in knowledge management. [17]

The research also revealed how proper knowledge management can help companies according to the respondents. The responses received were examined separately in the 3 company types. These results are summarized in the following table:

Table 1. The advatages of knowledge management for corporations and SMEs. [17]

\begin{tabular}{|l|l|l|l|}
\hline \multicolumn{1}{|c|}{ Type of business } & \multicolumn{1}{|c|}{ Large } & \multicolumn{1}{|c|}{ Medium } & \multicolumn{1}{|c|}{ Small } \\
\hline Improved quality of services & $66 \%$ & $\mathrm{n} / \mathrm{a}$ & $71 \%$ \\
\hline Increased comeptitiveness & $63 \%$ & $\mathrm{n} / \mathrm{a}$ & $51 \%$ \\
\hline Improved customer satisfaction & $60 \%$ & $75 \%$ & $54 \%$ \\
\hline Cost reduction & $57 \%$ & $60 \%$ & $\mathrm{n} / \mathrm{a}$ \\
\hline Improved effectiveness & $\mathrm{n} / \mathrm{a}$ & $78 \%$ & $56 \%$ \\
\hline Time savings & $\mathrm{n} / \mathrm{a}$ & $71 \%$ & $56 \%$ \\
\hline Improved management & $\mathrm{n} / \mathrm{a}$ & $60 \%$ & $57 \%$ \\
\hline
\end{tabular}

The table shows that employees working in different type of companies mentioned different benefits. Nevertheless, it is interesting that those working at large or small companies mentioned the "improved quality of services" in the first place. In comparison, employees working at medium-sized companies mentioned completely different advantages compared to those working in the other 2 types of companies. [17]

This research also examined what are the barriers that most hinder the proper management of knowledge according to employees. Employees working at large companies believe that the lack of financial resources (60 percent) is the biggest obstacle to knowledge management. 57 percent say ineffective communication, 51 percent say the fluctuation of 
specialists, 43 percent say lack of measurable benefits from knowledge management implementation and 42 percent say the wrong management style is what can prevent the introduction of knowledge management. 96 percent of respondents believe that knowledge could best be acquired through external training. Another 94 percent say an external - the so-called "third party expert", while 82 percent think that market research can also help. Previous experience was indicated by 73 percent, while negotiations (meetings) between managers and employees were marked by 72 percent. [17]

75 percent of employees at medium sized companies believe that inefficient communication is the main problem. 71 percent say the wrong management style and 61 percent say the lack of measurable benefits from knowledge management implementation is the biggest barrier to knowledge sharing. According to 86 percent of employees mark that the primary source of knowledge is the Internet. 75 percent say external training, while 73 percent think that professional literature can also help gain the important knowledge. According to the respondents, sources of knowledge can also be internal databases (63 percent), previous experience (52 percent), consumer opinions and feedback (51 percent), loyal employees who have been working for the company for a long time (46 percent), and unique knowledge and skills (46 percent). [17]

According to small business representatives, the biggest problems are ineffective communication (49 percent) and poor management style (47 percent). These barriers are followed by a lack of financial resources ( 40 per cent) and a lack of measurable benefits from knowledge management (37 percent). 63 percent of employees working in small businesses believe that databases can be the main source of knowledge. This source was followed by personal experience ( 55 percent), the Internet ( 54 percent), external training (43 percent) and literature review (41 percent). [17]

\subsection{Slovak enterprises}

In the case of Slovakia, the situation of knowledge management is relatively less researched. In this subchapter, we present the results of three studies that can be highlighted in some respects. One of them is related to the name of Tóbiás Kosár, Gódány and Szabó [20]. The authors examined 360 companies from three Slovakia districts (Komárno, Dunajská Streda, Nové Zámky). 73 percent of the enterprises participating in the research are micro and 11 percent small. $8 \%$ were medium-sized and $8 \%$ were large enterprises.

The answers show that 73 percent of respondents said that knowledge management plays an important role in corporate strategy. All large companies consider knowledge to be a tool of strategy. The research reveals that the majority of Slovak entrepreneurs have already recognized the importance of knowledge management, but the appropriate financial resources are't available for implementation. Most micro-sized enterprises do not have their own statements showing how much they spend to properly manage their knowledge. For companies that still have such a statement, only 0-2 percent of the total cost is spent on knowledge management. The situation is similar for small businesses. 45 percent of medium-sized companies spend 5-6 percent of their total cost on knowledge management. 43 percent of the surveyed large-sized companies spend 10 percent of their total spend on knowledge management. [20]

Gabris et al. [18] and Sujanova et al. [19] examined the maturity level of knowledge management in industrial companies. Their research was based on 86 completed questionnaires. The study reveals how companies relate to the implementation of knowledge management. 


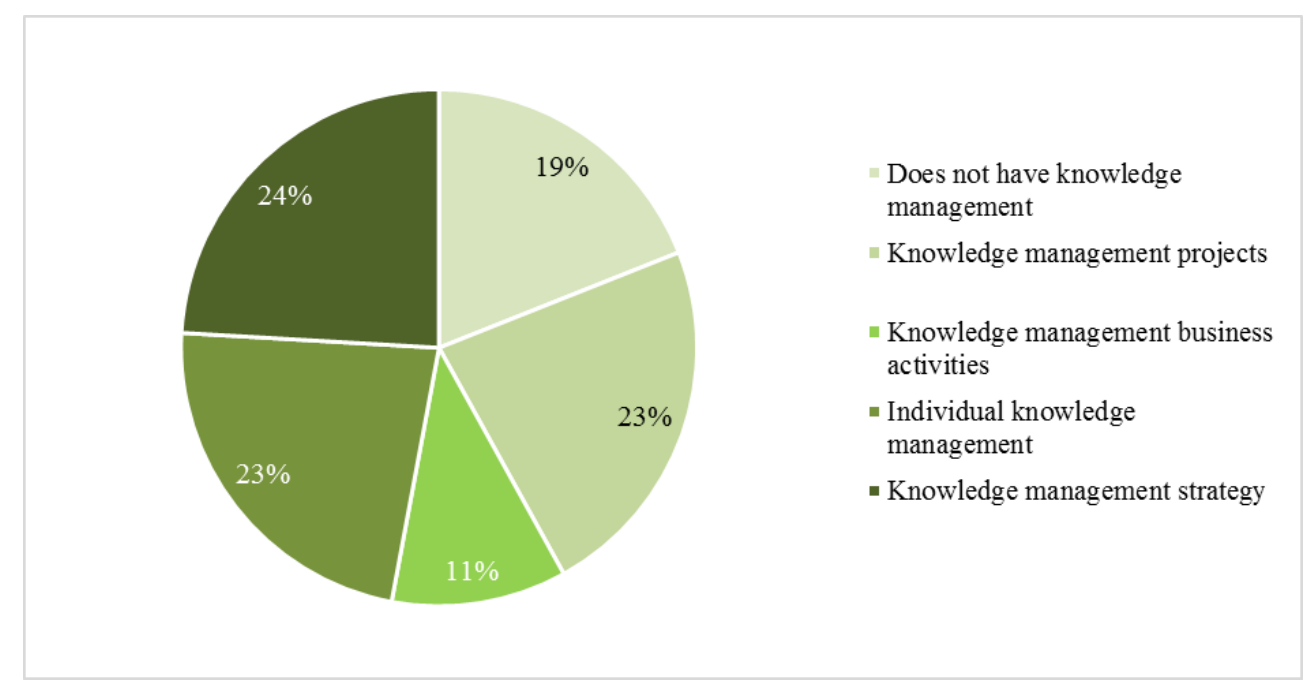

Fig. 5. The state of KM at Slovak industrial enterprises. [18, 19]

$24 \%$ of participating companies have a knowledge management strategy. Another 23 percent have knowledge management projects, while 23 percent said that knowledge management works in an individual way within the company, so it is not "centrally" organized. In our opinion, this is a somewhat surprising result, since the right knowledge requires the right person to be guided and planned. It cannot "break the road" on its own. $19 \%$ of filling companies do not perform any form of knowledge management. We believe this is a relatively high rate. $11 \%$ of respondents indicated that their business was based on knowledge management. [18, 19]

The researchers also looked at employees' access to knowledge. According to the results, 57 percent of those who completed the survey believe that their organization has relatively easy access to the knowledge they need. In contrast, the proportion of those who think they have less access to the necessary knowledge is 15 percent. $28 \%$ of respondents indicated a moderate opportunity. Based on these answers, it is certainly positive that such a high percentage of people have access to the knowledge they need at any given time. The answers to this question are detailed below. [18, 19] 


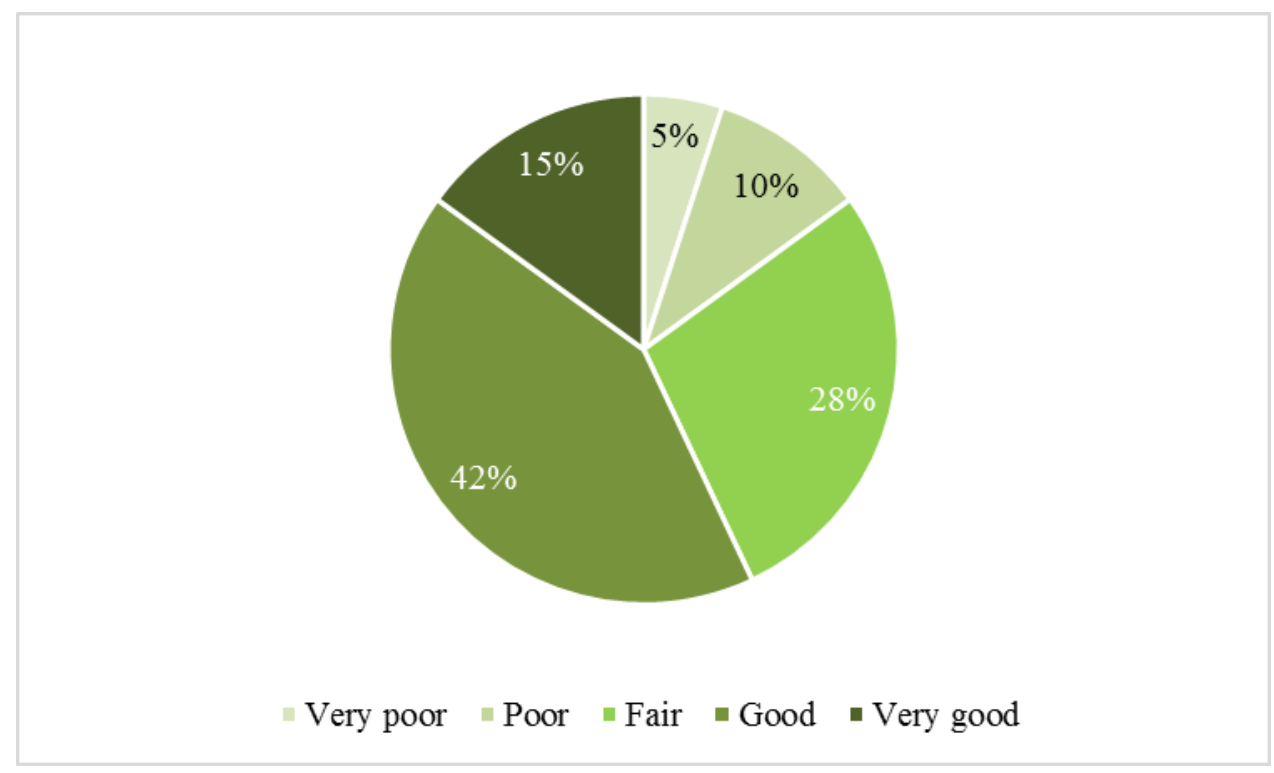

Fig. 6. Access to the company's knowledge. [18, 19]

\section{Conclusions}

In our study, we examined the relationship between knowledge management in companies in 2 countries using secondary data. Since our data came from several different studies, it wasn't possible to fully compare their results. Some studies have focused merely on certain areas of competition, while others have focused only on certain company sizes. Occasionally, some studies have investigated other factors that our research doesn't address. Because of that the results of these studies were of limited use. Comparison is also complicated by the fact that some studies have worked with relatively lower number of items.

Nevertheless, some similarities can still be found between the 2 countries. When we look at size, it is usually large companies that are more engaged in knowledge at some level. These companies have more sophisticated assets. One of the biggest obstacles to knowledge management is that the management and the employees have less time and information about the management of knowledge. In order to improve in the future, it is worth raising the awareness of companies about the usefulness of knowledge management. We believe that knowledge will become more and more important in the future, so we need young employees who are aware of it and are open to share their own knowledge in order to make the enterprises more successful.

\section{Acknowledgement}

This work was supported by the Collegium Talentum 2019/20 Programme of Hungary.

\section{References}

1. Penrose, E. The theory of the growth of the firm. Oxford: Oxford University Press (1959) 
2. Davenport, T., Prusak, L. Working knowledge: how organizations manage what they know. Cambridge: Harvard Business School Press (1998)

3. Bencsik, A. Miért nem müködik? Tudásmenedzsment magyar módra. Tudásmenedzsment 15, 1 (2014)

4. Bencsik, A., Juhasz, T., Mura, L., Csanadi, A. Formal and informal knowledge sharing in organisations from Slovakia and Hungary. Enterpreneurial Business and Economics Review 7, 3 (2019)

5. Mura, L., Gontkovicova, B., Dulova Spisakova, E., Hajduova, Z. Position of employee benefits in remuneration structure. Transformations in Business \& Economics 18, 2 (2019)

6. Chaudhry S.S., Li Y., Ren N. An enterprise knowledge management system based on the use case model. Research and Practical Issues of Enterprise Information Systems II. IFIP International Federation for Information Processing 255 (2008)

7. Drucker, P. F. Post-capitalist society. New York: Routledge (2011)

8. Hitka, M., Lorincova, S., Bartakova, G. P., Lizbetinova, L., Starchon, P., Li, C., Zaborova, E., Markova, T., Schmidtova, J., Mura, L. Strategic Tool of Human Resource Management for Operation of smes in the Wood-processing Industry. Bioresources 13, 2 (2018)

9. Wielka Encyklopedia. Warsawa: Wydawnictwo Naukowe PWN (2005)

10. Hittmár, Š. Manažment. Žilina: EDIS (2006)

11. Vlacseková, D. Differences of motivation in public and private organizations. Aktuálne problémy podnikovej sféry 2018 - Zbornik vedeckých prác, 1077-1085 (2018)

12. Peracek, T., Noskova, M., Mucha, B. Selected issues of Slovak business environment. Economic and Social Development (ESD): Managerial Issues in Modern Business, 254-259 (2017)

13. Gholami, M. H., Asli, M. N., Nazari-Shirkouhi, S., Noruzy, A. Investigating the influence of knowledge management practices on organizational performance: an empirical study. Acta Polytechnica Hungarica 10, 2 (2013)

14. Bencsik, A., Juhasz, T., Seben, Z. The importance of informal knowledge sharing (workplace gossip) in organizations. Environment. Economic and Social Development (ESD), 46-57 (2019)

15. KPMG Knowledge Advisory Services. Insights from KPMG's European KPMG Polska. (2004). Zarządzanie wiedza w Polsce 2004. Warsawa: KPMG Polska (2004)

16. Siuta-Tokarska, B. Challenges and problems of knowledge management in enterprises in Poland. China-USA Business Review 12, 2, (2013)

17. Chmielewska-Muciek, D., Zinczuk, Z. Knowledge management in it companies in Poland. Human Capital without Borders: Knowledge and Learning for Quality of Life: Proceedings of the Management, Knowledge and Learning International Conference 2014, 279-288 (2014)

18. Gabris, P., Bielik Marettová, M., Pavlenda, P., Ličko, M., Šujanová, J. Knowledge management maturity aspects in industrial enterprises. 8th International DAAAM Baltic Conference Industrial Engineering, 454-457. (2012)

19. Sujanova, J., Gabris, P., Licko, M. Aspects of knowledge management in Slovak industrial enterprises. Proceedings of The 13th European Conference on Knowledge Management, Vols 1 and 2, 1135-1144 (2012) 
20. Tóbiás Kosár, Sz., Gódány, Zs., Szabó, T. Culture and knowledge management in organizations in Slovakia. 5th Central European Conference in Regional Science (CERS, 2014), 1063-1073 (2014)

21. Jaki, A., Siuta-Tokarska, B. New imperative of corporate value creation in face of the challenges of sustainable development. Enterpreneurial Business and Economics Review 7, 2 (2019)

22. Raport o stanie sektora matych i średnich przedsiębiorstw $w$ Polsce $w$ latach 20082009. Warszawa: Polska Agencja Rozwoju Przedsiębiorczości, PolishAgency for Enterprise Development (2010)

23. Wolański, R. Wiedza i innowacje w matych i średnich przedsiębiorstwach-Postęp czy stagnacja. Warsawa: University of Warsaw (2007) 